\title{
SUBTITLING FOR STREAMING PLATFORMS: NEW TECHONOLOGIES, OLD ISSUES
}

\author{
Giovana Cordeiro Campos 1 \\ Thais de Assis Azevedo 1 \\ 1Universidade Federal Fluminense, Niterói, Rio de Janeiro, Brasil
}

\begin{abstract}
This article discusses part of the translation process for subtitling on streaming platforms. Based on the theoretical framework of Translation Studies, more specifically Audiovisual Translation, we provide a state-ofthe-art survey of the field, given that streaming is a new technology with implications for the field of translation. As a study corpus, the first season of the Netflix series Outlander is analyzed, focusing on the subtitle review process and reading speed. It was observed that technological innovations seem to reinforce old issues, such as the belief in total fidelity.
\end{abstract}

Keywords: Streaming; Subtitling; Translation Studies

\section{LEGENDAGEM PARA PLATAFORMAS DE STREAMING: NOVAS TECNOLOGIAS, VELHAS QUESTÕES}

\begin{abstract}
Resumo: Este artigo discute parte do processo de tradução para legendagem em plataformas de streaming. Tomando como base o referencial teórico do campo dos Estudos da Tradução, mais especificamente a Tradução Audiovisual (TAV), busca-se investigar e compreender o que há de novo nesse campo, uma vez que se trata de uma nova tecnologia - o streaming - , que tem implicações para o campo da tradução. Como corpus de estudo é analisada a primeira temporada da série Outlander, disponível na Netflix, com o foco nos processos de revisão das legendas e no da velocidade de leitura. Observou-se que as novidades tecnológicas parecem reforçar velhas questões, como a da crença na fidelidade total.

Palavras-chave: Streaming; Legendagem; Estudos da Tradução
\end{abstract}




\title{
Introduction
}

The world is becoming increasingly virtual and technological, and the restrictions imposed by the COVID-19 pandemic appear to have intensified this process. Today, anything is just a click away on the Internet through a small device that fits in the palm of one's hand: the smartphone. The catchphrases of the day are "technology" and "innovation" and, as soon as they are launched, "new" devices already border on obsolescence. The discourse of novelty leads us to continually look for something more powerful, faster, and, supposedly, "better":

\begin{abstract}
the expression new technologies is, today, necessarily related to that of obsolescence [...] it is necessary to create fascinating new technologies that soon become obsolete when another technology - a newer and even more fascinating one - is created, which is also expected to quickly become obsolete. New and technology are words that, as part of the social order of the globalized market economy, produce the effects we understand today as technology. (Ferreira 76; our translation, emphasis added)
\end{abstract}

Speed seems to be central in the capitalist world, and discourse that technology allows greater efficiency and speed is hegemonic (Mello; Campos).

The relationship between technology and capitalism seems to be a fundamental issue, not only in laptop and smartphone production, but in translation production as well, since it defines and maintains speed as a kind of market law (Campos). And this "law" is not lost on the translator, since time is money and the basis of capitalism is profit.

If, on the one hand, the pandemic has forced even the most reticent to adapt to the reality of remote work and communication, on the other, it has made us rethink little by little the functioning 
of this process ${ }^{1}$, as well as the functioning of human beings in society. In education, for example, even generations born after the advent of smartphones (i.e. highly "technological" individuals) are now longing for face-to-face contact with their teachers and colleagues. Thus, it is necessary to (re)think technology and its impact on society. In the present article, we are interested in the relationship between technology and translation, specifically the translation used in subtitles on streaming platforms ${ }^{2}$.

A starting point for our discussion is the meaning of "technology" today, something that is closely related to computers and the Internet. According to Ferreira (2015), technology seems restricted to certain fields of knowledge, such as the exact sciences and engineering, and is thus, on some level, considered as "forbidden" to be produced in other fields (both on a common sense and a market level). Under such conditions, a hierarchy is formed in which some fields are superior to others, i.e. the position of exact $v s$. human sciences on a global scale.

However, historically speaking, technologies have been produced in the field of language, for example, that have had a great impact on society, contributing to the construction and transmission of human knowledge. We can cite, with Ferreira (2015), the work of Auroux ((a), (b)), whose research indicated that the two greatest technoscientific revolutions were two language technologies: the invention of writing and grammatization. The first produced profound changes in language practices, allowing for the recording of laws and scientific discoveries (Ferreira 78). Regarding the second, grammar and dictionaries have been considered fundamental for the modern sciences:

1 See, for example the article "Corporações tentam acelerar distopia tech". Available at: https://outraspalavras.net/outrasmidias/naomi-coporacoes-tentamacelerar-distopia-tech/.

${ }^{2}$ This article is a joint production by the authors as an offshoot of Thaís de Assis Azevedo's master's dissertation, entitled Legendagem para Streaming: novas práticas (2020), which was supervised by Dr. Giovana C. Campos (Universidade Federal Fluminense, Niterói, RJ, Brazil).

Cad. Trad., Florianópolis, v. 40, n⿳ 3, p. 222-243, set-dez, 2020. 
The occurrence of these two technoscientific revolutions is linked to other technologies which, in history, have served as support for their consolidation, among which we can point out, for example, the parchment, the book, the voice recorder and, from the 20th century, the computer, or from the 21 st century, the tablet, iphone, etc. In cyberspace, language functions in different ways such that, in addition to writing, speech and image can also appear. With this in mind, researchers from the Auroux team have already considered the possibility of a third technoscientific language revolution that has arisen from the relationship between language and the Internet/computers. (Mariani and Medeiros 15; our translation).

Thus, it is more useful to think of these different areas as being in dialogue, rather than opposition. Furthermore, the global circulation of "products" (scientific discoveries, news, devices, etc.) does not occur without various modes of translation. Such a relationship, however, is not new, since translation has been present for centuries in human interchange ${ }^{3}$, whether scientific, cultural, or economic in nature.

One of the most visible technological innovations of recent decades is streaming, whose platforms have had a profound impact on both the production and distribution of audiovisual material and which involve, among other factors, translated subtitles.

\section{Streaming and Subtitling}

Streaming can be understood as a:

Content distribution process, via the Internet, in which the user begins viewing files without having to download

\footnotetext{
${ }^{3}$ See, for example, the seminal work of Delisle J .; Woodsworth, J. Translators Through History. Amsterdam: John Benjamins Publishing Company, 1995.
} 
them, allowing quicker viewing with the content displayed sequentially, as it arrives at the user's computer. The user will be viewing the contents of the files at the rate they arrive, requiring only a small initial waiting time for the synchronization process and the creation of a temporary memory (buffer) used to store a few seconds of content, to absorb changes in the reception rate and/or temporary connection breaks. (Adão 21; our translation)

Netflix, one of the most popular streaming platforms (currently with more than 130 million subscriptions in more than 190 countries), was founded in 1997 in the United States as an online movie rental/sale service. In 2007, the company began online transmission, allowing subscribers to watch series and movies instantly on their computers (Ladeira). The company arrived in South America in 2011, and had expanded worldwide by $2016^{4}$. In Brazil, the use of streaming platforms has become popular in recent years with the advent of high-speed Internet, especially in the most urbanized regions of the country.

As addressed in a number of articles ${ }^{5}$, new technologies, including streaming, have impacted the work of translators. These technologies have allowed the construction of large translation memories, greater research resources and contact between companies, translators and clients. However, easier sharing and division of labor have sped up the flow of information and the need to disseminate it quickly, resulting in increasingly tight deadlines and new problems for translators. According to Gil and Pym (2006):

\footnotetext{
${ }^{4}$ Available on the official Netflix website: https://media.netflix.com/pt_br/aboutnetflix. Acessed on October 16, 2018.

${ }^{5}$ See, for example, Rocha, M et al. Cadernos de Tradução. v.2. Florianópolis, UFSC, 2004; Cronin, M. Translation and Globalization. London, NY: Routledge, 2003; Cronin, M. Translation in the Digital Age. London, NY: Routledge, 2013; Stupiello, E. N. A. Ética Profissional na Tradução Assistida por Sistemas de Memórias. São Paulo: UNESP, 2014.
} 
Technology is not an option in today's professional world; it is a necessity. [...] On countless levels, the advantages presented by technology are so great that they cannot be refused. Electronic media offers numerous advantages for contacts with clients and other translators. Translation memories perform the most repetitive tasks so that translators can concentrate on the most creative aspects of translation. The intelligent use of machine translation should mean that our best human efforts are focused where they are most needed. But technology is not perfect, and translators must be very aware of those imperfections. (17)

However, despite their "imperfections", discourses on translation consider machines much more efficient than humans, even in the field of translation. Subtitling is closely related to technology, mainly due to the type of translations involved and the need for specific software (Martinez). As a result, it is also affected by such discourses and practices.

We see today in the translation market, especially in areas more closely linked with technology (such as subtitling for streaming and localization), a tendency to use platforms that allow translators to work online, which free them from downloading and storing audiovisual and text files. Although traditional subtitling programs are still frequently used, proprietary platforms, such as that of Netflix, are becoming more common. This trend is growing, especially in companies that translate/subtitle into several language pairs and have several international branches, since using such platforms minimizes their risks and increases their reach when hiring professionals who, despite being based at different points on the planet, will have simultaneous access to the material. The platforms prevent data leaks and, thus, improper sharing of content, which can cause great inconvenience to studios, translation agencies, translators, etc.

By eliminating the need to download and upload files, they also allow multiple subtitlers to work on the same project 
simultaneously. All of the episodes of a series, for example, can be subtitled in a single day, each by a different translator. In addition to the subtitle proofreader, other positions have developed, such as "quality checkers" and "conformers" (other nomenclatures exist in other fields, such as business), who work post-translation on collation and proofreading. Thus, even at the review stage, several professionals may be involved. To provide an idea of the complexity of the involved workforce, in a series of 12 episodes, there could be up to 24 professionals directly responsible for creating the subtitles, just counting one different translator and reviewer for each episode. Therefore, one impact of new media technologies is a greater fragmentation of the translation/subtitling task ${ }^{6}$. A resulting problem is the consistency of the subtitles, since the same term might be translated differently by different translators throughout the series, creating confusion for viewers ${ }^{7}$. We believe that a more structured review process is necessary to account for the variety of different translation possibilities produced by different translators. In addition, closer dialogue between translators and proofreaders, as well as more specific instructions regarding a particular series or production are required.

Another novelty in subtitling platforms for streaming compared to traditional subtitling programs is that the translators receive the lines pre-segmented and time-stamped, in addition a practically complete transcription. ${ }^{8}$ The translator/subtitler has access to speech transcription in the source language ${ }^{9}$ and audiovisual material through the platform. Thus, simply put, the translator/

${ }^{6}$ Researchers such as Maria Paula Frota and Giovana Cordeiro Campos have addressed this fragmentation of the translator's task in classes and lectures. Campos, in the article "Tradução e Mercado: uma análise discursiva" (2017), available in bibliographic references, calls this process "spraying".

${ }^{7}$ See, for example, Thais de Assis Azevedo's master's thesis, already cited and listed in the reference section.

${ }^{8}$ This information about subtitle timing was obtained from the professional experience of one of the authors and from other colleagues in this field.

${ }^{9}$ Recalling that it is possible to use indirect translation, i.e., translating based on translations into English.

Cad. Trad., Florianópolis, v. 40, n⿳ 3, p. 222-243, set-dez, 2020. 
subtitler "inputs" the subtitles into the space corresponding to the original transcription. It is possible to adjust the entry and exit times, although company manuals usually advise against it.

One problem with this work method is that, frequently, too little time is allotted for sounds and phrases, since segmentation seems to occur according to the timing of the lines, which can be very fast. Thus, if the translator/subtitler does not have a minimum understanding of segmentation and timing, the subtitle may flash too briefly on the screen to be $\mathrm{read}^{10}$. The translator/subtitler can change the time-stamps, although for some companies they must provide a written justification for doing so, and the recommendation/ custom is that no such changes should be made. Considering the increasingly short deadlines, pondering such issues and justifying such choices means spending more time on production, which is a problem in capitalist systems. There are, therefore, external factors to translation that shape the way translators/subtitlers make their translation "choices".

Thus, streaming allows audiovisual material to be translated in a process similar to the translation of written texts. In other words, it is possible, although not recommended, for the translation to be carried out as mere written text, inputting the translated text into the provided subtitle space without consulting the audiovisual content. However, audiovisual productions include images and sounds that are linked with the dialog. When faced with a short deadline, a translator/subtitler who is not well-versed in subtitling practice, including the minimum and maximum time a subtitle can spend on screen and the reading speed of the potential audience (which involves issues such as literacy), may simply translate the transcribed text and produce unreadable subtitles (either because they appear on screen for too short a time or are too long to read in the available time). Thus in Gottlieb's terms (1994), such subtitling

\footnotetext{
${ }^{10}$ It should be noted that one of the motivations of the authors for conducting this study was that both they and their family members had difficulties reading the subtitles of films featured on streaming platforms.
}

Cad. Trad., Florianópolis, v. 40, n⿳ 3, p. 222-243, set-dez, 2020. 
would cease to be a diagonal translation and would become a horizontal translation, i.e. without changing the code, since it would pass from one written text (the pre-segmented time-stamped transcription) to another (subtitles).

The division of subtitles into pre-segmented time-stamped "boxes" is close to the translation method in several CAT Tools ${ }^{11}$, where the source text is segmented on one side and the translator must input the translation on the other. As noted by researchers in the field of computer-assisted translation ${ }^{12}$, we believe that, although translation tools facilitate several aspects of translation work and are mandatory in some areas of translation, especially those closely related to technology or areas involving tighter deadlines, text segmentation (in either the source and target text) can impede the flow of writing, as well as the translator's control over his/her own work. This is due to the fact that both the text and the translator must "obey" the "boxes" predetermined by the program. In the case of streaming platforms, translators, proofreaders, quality checkers and other agents have equal access to transcription and/ or transcription and translation, as well as the relevant audiovisual material. Nevertheless, all of these agents could still approach the process by focusing only on the written text.

In Translation Studies, translation is understood as a complex cultural process that involves both the source and target contexts, as well as the socio-historical and political-ideological elements that shape all translations. However, traditionally, especially according to common sense, the translation must be a "faithful copy" of the source text, hence concepts such as total fidelity and

11 Computer-Assisted Translation (or Computer-Aided Translation tools) are programs that facilitate the work of the translator and allow visualization of the source and target text in segmented fields. In addition, CAT Tools generally allow the incorporation of translation memories, glossaries and dictionaries. It is important to point out that CAT Tools are not automatic translation tools. Some examples include: SDL Trados Studio, Wordfast, MemoQ, OmegaT and SwordFish.

${ }^{12}$ See, for example, Cadernos de Tradução 2(14) (2004). 
equivalence, which are already outdated in Translation Studies. The discourse on "total fidelity" in translation is problematic (Campos), especially for subtitling, since the principles that shape it are synthesis and simplification. In an audiovisual production the viewer must be allowed to process and interpret the images and sounds, as well as read the subtitles, which are an addition burden on attention. If everything is translated, viewers will spend all their time reading the subtitles, rather than watching the onscreen action. Multilingual viewers who can understand both the source text and the target text, frequently criticize "kleptomaniac" translators/subtitlers ${ }^{13}$.

To illustrate some of the issues discussed here, we will address two points of interest. First we will review the impact of the review process on viewers, after which we will assess subtitle quality in view of reading speed. As an object of analysis, we selected the Outlander series, produced by Starz and broadcast first by Fox and later by Netflix.

\section{Revision Practices}

Revision is an important step of the translation process. Both academic studies and market practice agree that the review process should not be neglected and that it helps maintain high translation standards. In general, the translator performs a review after completing the translation and, usually, at least one further review is performed by a second professional from the company that contracted the service. Revision is also a well-established practice in the audiovisual translation (AVT) market, especially in the subtitling field. Although companies and AVT agencies use different names for the review process, with some dividing it into two or more stages, or even classifying it as "quality

${ }^{13}$ Here we are referring to Dezsö Kosztolányi’s short story “The Kleptomaniac Translator".

Cad. Trad., Florianópolis, v. 40, n⿳ 3, p. 222-243, set-dez, 2020. 
control" and "quality check", the process itself remains similar. In the AVT market, professional translators and subtitlers are usually self-employed and provide services to both translation agencies and direct clients. It is common for agencies to include both external review by an independent contractor and internal revision company employees.

Here, we analyze excerpts of Brazilian Portuguese (PT-BR) ${ }^{14}$ subtitles from the first season of the Netflix series Outlander to better understand the review processes used in streaming platforms. Outlander is based on the homonymous book series by Diana Gabaldon first published in 1991. The narrative revolves around the relationship between Claire Randall, a time traveler from 1940s England, and James Fraser, a man from 1740s Scotland. The first season of the series is set in 1740s Scotland.

The subtitles of Outlander provide a broader view of its review process, which we will discuss using a number of excerpts. Although it is not our intent to dwell on translator errors (as other traditional studies have done), we do intend to reflect on why they occurred.

Table 1: Selected subtitle issues in season one of Outlander

\begin{tabular}{l|l|l|l}
\hline Episode & Character & English audio & $\begin{array}{l}\text { Brazilian Portuguese } \\
\text { subtitle }\end{array}$ \\
\hline 1 & James Fraser & Thank you, sassenach. & Obrigada, Inglés. \\
\hline 8 & Laoghaire & $\begin{array}{l}\text { You dinna look very } \\
\text { happy. }\end{array}$ & $\begin{array}{l}\text { Você não prece muito } \\
\text { feliz. }\end{array}$ \\
\hline 10 & $\begin{array}{l}\text { The Duke of } \\
\text { Sandringham }\end{array}$ & $\begin{array}{l}\text { Always a pleasure to } \\
\text { visit Clan MacKenzie! }\end{array}$ & $\begin{array}{l}\text { Sempre um prazer } \\
\text { visitar Clan } \\
\text { MacKenzie! }\end{array}$ \\
\hline 10 & James Fraser & $\begin{array}{l}\text { With Arthur gone } \\
\text { there'll be no one to } \\
\text { protect her from her } \\
\text { own reputation }\end{array}$ & $\begin{array}{l}\text { Com Arthur fora,/ } \\
\text { ninguém a protegerá } \\
\text { de sua própria } \\
\text { reputação }\end{array}$ \\
\hline
\end{tabular}

14 PT-BR and EN will be used hereafter to refer to Brazilian Portuguese and English, respectively.

Cad. Trad., Florianópolis, v. 40, n⿳ 3, p. 222-243, set-dez, 2020. 


\begin{tabular}{l|l|l|l}
\hline 11 & $\begin{array}{l}\text { James Fraser } \\
\text { (voice-over) }\end{array}$ & $\begin{array}{l}\text { With Arthur gone } \\
\text { there'll be no one to } \\
\text { protect her from her } \\
\text { own reputation }\end{array}$ & $\begin{array}{l}\text { Com Arthur fora,/ } \\
\text { ninguém a protegerá } \\
\text { de sua própria } \\
\text { reputação }\end{array}$ \\
\hline
\end{tabular}

Source: The authors

The first example in Table 1, <Obrigada, inglés $>$, involves two gender issues. Although the speaker is a man (Jamie), the subtitle uses the feminine form (i.e. obrigada instead of obrigado). "Inglés" is also incorrect, not only because a woman is being addressed (i.e. inglesa), but also due to an orthographic (presumed typographical) error (i.e. inglês rather than inglés, which doesn't exist in any variety of Portuguese). Such an error could have easily been detected by an automatic spellchecker, a component of most subtitling programs, platforms, and text editors.

The second example also involves a typographical error, prece instead of parece. This error would not have been detected by the automatic spellchecker, since it is a legitimate word (meaning a prayer $)^{15}$. Although more sophisticated spellcheckers can detect construction and grammatical issues, we cannot infer that one was involved in this case. Nevertheless, this error could have been identified and corrected by re-reading, although tight deadlines might have prevented the translator from preforming a careful (or any) re-reading.

The third example includes an EN word, "clan", in the PT-BR subtitle. Since "clan" has a PT-BR correspondent (clã), this switch could have confused viewers, compounded by the capitalization, which would not have occurred in PT-BR. We speculate that this was a failure in the review process. Although we could not obtain information from Netflix about the subtitling process for Outlander or even about which companies or individuals provided the service, we do know that deadlines are increasingly tight and,

${ }^{15}$ It is relevant to mention that we also found typographical errors in other subtitled films on Netflix and Amazon Prime.

Cad. Trad., Florianópolis, v. 40, no 3, p. 222-243, set-dez, 2020. 
as we have already mentioned, this could leave very little time for human review (perhaps none at all). If not used intentionally, "clan" would have been easily detected by the spellchecker, since it is not PT-BR. However, provided sufficient time for re-reading/ review, this issue would have been identified and addressed.

These first three examples reveal problems with the review process, since they could have been identified and resolved through automatic spellchecking or human review, provided sufficient time. This raises two important questions about the review process : i) whether sufficient time was allotted for the translator to revise his/her own work; and ii) whether a second professional proofread the subtitles.

Concerning the final two examples, the same subtitle appears both in the tenth and eleventh episodes of the series. In its first appearance, Jamie (speaking to Claire) refers the death of Arthur Ducan, which occurred previously in the same episode. The subtitler translated "gone" as fora, although "gone" means "dead" in this case, not the literal translation used in the subtitle ("away"). Arthur is dead, his death had just been shown a few minutes previously. The same subtitle also appears in the following episode, but as a flashback: Jamie speaks in voice-over while Arthur's death is shown again. Despite the consistency, however, the subtitles have not considered the on-screen content, since the events of the series clearly contradict the idea provided in the text.

In subtitling platforms, the video usually comes with a timing/ spotting template ( $c f$. Pedersen 85) and a transcription of the dialogue. With the transcription located on one side of the screen and the pre-timed box where the translation is to be input on the other, the translator could easily translate the audiovisual production horizontally rather than diagonally (Gottlieb 104). This practice is neither suggested nor implied by clients or translation agencies, but due to increasingly tight deadlines, as our corpus shows, it can happen ${ }^{16}$. To the degree that the translation is based on only a script

${ }^{16}$ Although we could suppose that the subtitler was tired and not paying attention

Cad. Trad., Florianópolis, v. 40, n⿳ 3, p. 222-243, set-dez, 2020. 
or audio transcription, subtitling, a mode of AVT, is similar to text translation. However, subtitling necessarily involves condensation, rephrasing and other strategies. Given that different velocities are involved in reading and speaking, it is not advisable to translate "word for word", ignoring the relationship between image, sound and text. These two excerpts indicate that sufficient time must be allocated for proper review.

\section{Reading Speed}

Netflix's style guide recommends 17 characters per second as a reading speed and a maximum of 42 characters per line. According to Carvalho's (2005) discussion about reading speeds in Brazilian subtitles, the Netflix guideline exceeds the average rate used in national television, cinema, VHS and DVDs. On the other hand, nowadays the reading speed used by worldwide streaming services varies from 17 to 20 characters per second (CPS) ( $c f$. Szarkowska and Gerber-Morón 2), so Netflix's standard could be considered acceptable. Besides "subtitle speeds are not set in stone; they differ from country to country and even from company to company" (Szarkowska and Gerber-Morón 2). The suggested reading speed in Netflix' PT-BR style guide is the same as that of its style guides for other languages, and " $[\ldots]$ since the reading speed remains the same for all languages, there is very little incentive for subtitlers to actually carry out much condensation, as this is arguably not only 'one of the most timeconsuming elements of the job' (Szarkowska and Gerber-Morón 14) but also a cognitively taxing task" (Pedersen 96).

We compiled the number of characters per line and analyzed the reading speed in each episode of the first season of Outlander to

to the scene, the result is problematic considering its impact on viewers. We must point out, though, that the problem could have been resolved by allowing sufficient time for a second round of review by another professional.

Cad. Trad., Florianópolis, v. 40, n⿳ 3, p. 222-243, set-dez, 2020. 
compare them with both the Netflix style guide and AVT research over the years. Each episode is approximately 45 minutes in length and has an average of 672 subtitles. The entire season includes 10,759 subtitles. The subtitles were collected from the Netflix platform and were input into Subtitle Edit to determine the reading speed. No subtitle exceeded 42 characters per line, although 14 of the 16 episodes contained subtitles that reached the maximum number of characters.

Table 2: Subtitle reading speed in season one of Outlander

\begin{tabular}{l|l|l|l}
\hline Episode & $\begin{array}{l}\text { Number subtitles } \\
\text { in the episode }\end{array}$ & $\begin{array}{l}\text { Subtitles lasting } \\
\text { less than 1 sec }\end{array}$ & $\begin{array}{l}\text { Number of subtitles } \\
\text { over 17 cps }\end{array}$ \\
\hline 1 & 700 & 1 & 256 \\
\hline 2 & 672 & 5 & 203 \\
\hline 3 & 800 & 0 & 330 \\
\hline 4 & 632 & 4 & 230 \\
\hline 5 & 654 & 0 & 183 \\
\hline 6 & 766 & 1 & 278 \\
\hline 7 & 670 & 0 & 181 \\
\hline 8 & 714 & 1 & 242 \\
\hline 9 & 676 & 2 & 235 \\
\hline 10 & 730 & 2 & 255 \\
\hline 11 & 629 & 2 & 173 \\
\hline 12 & 694 & 2 & 253 \\
\hline 13 & 680 & 1 & 239 \\
\hline 14 & 728 & 1 & 324 \\
\hline 15 & 512 & 1 & 161 \\
\hline 16 & 502 & 2 & 178 \\
\hline CPS $=$ Characters per second &
\end{tabular}

Source: The authors

Cad. Trad., Florianópolis, v. 40, no 3, p. 222-243, set-dez, 2020. 
As Table 2 shows, every episode contains numerous subtitles over the recommended reading speed. In 13 of the 16 episodes, at least $30 \%$ of the subtitles exceed $17 \mathrm{CPS}$, and the percentage remained high in the other three (approximately 27\%). There were also several very fast subtitles (i.e. $<1$ second). Since we have no access to the subtitlers' reasoning, we cannot state with any certainty why so many subtitles are above the recommended reading speed. Nevertheless, we noticed a trend towards less condensation, as discussed by Pedersen (b), since greater condensation would result in shorter subtitles and, consequently, a better chance of meeting the recommended reading speed (and a better user experience). We can also assume that subtitles with more characters per line and CPS may indicate a belief that "more space equals more information" (reviving ideas of total fidelity), which does not necessarily imply higher quality. As mentioned above, subtitling involves both the text (the subtitle itself) and the on-screen action. Maintaining a manageable reading speed is important so viewers can both read the subtitles and follow what happens on-screen with no rereading. It is worth considering the impact of high-speed subtitles on the experience of viewers who are less accustomed to subtitled programming and/or have some degree of vision impairment.

Reading subtitles is, of course, directly related to reading habits and, inevitably, to literacy. While some segments of the population may be accustomed to everyday reading, others are less used to it and might encounter difficulties with subtitles that require high reading speeds. Subtitles presenting a long text in a short time demand greater reading skills and, thus, are an obstacle to accessibility. Literacy refers "to the use and social practices of reading and writing ${ }^{17}$ " (Minucci and Cárnio 228), and researchers have defined reading as "an interactive process that involves different perceptual, auditory, visual, cognitive and linguistic skills that are interrelated and allow the reader to develop from decoding to

17 “Ao uso e práticas sociais de leitura e escrita” (Minucci and Cárnio 228).

Cad. Trad., Florianópolis, v. 40, n⿳ 3, p. 222-243, set-dez, 2020. 
understanding" ${ }^{18}$. The same process occurs while reading subtitles, considering that some the linguistic information is derived from the original audio (through elements of prosody, for example) and onscreen content, in addition to the written text. Thus, it is important to think about subtitling practices and technical parameters that are accessible to different social groups, guaranteeing the maximum possible audience.

We observed that the Netflix Outlander subtitles were often on-screen for a short time and involved a relatively high reading speed. Moreover, numerous subtitles in every episode surpassed the 17 CPS limit. Although the Netflix recommendation of 17 CPS seems to be based on worldwide streaming averages ${ }^{19}$, it does not necessarily mean that this rate corresponds to viewer preferences in general, much less those of Brazilian audiences. It seems to us an attempt to introduce as much information as possible in the subtitles, transforming them into a kind of transcription in the target language, which is hardly the goal of AVT. Our point is that this is directly related to the issue of total fidelity and, therefore, to an outdated mindset about translation that is resurfacing, especially in connection with new technologies. It should be pointed out that the agents involved in this translation process did not condense or reduce the text in most of the subtitles, despite the tradition of theory and practice that defines subtitling as a synthesis process due to the fact that viewers need enough time to watch the onscreen action, listen to dialogues, and read the subtitles. Finally, we understand that one objective of subtitling is to guarantee access to all, i.e. those with and without high reading speeds. Other

\footnotetext{
18 "Um processo interativo que envolve diferentes habilidades perceptuais, auditivas, visuais, cognitivas e linguísticas que se inter-relacionam e dão condição para que o leitor desenvolva desde a decodificação até a compreensão" (Minucci and Cárnio 228).

19 Actually, for video on the Internet and streaming platforms, it is generally considered that viewers can stop the video, rewind and read the subtitles again. However, for movies and series, this would interrupt the action and interfere with the "cinematic experience".
} 
accessibility issues should also be considered, such as visually- or hearing-impaired viewers, etc.

\section{Conclusion}

Streaming platforms, such as Netflix, are gaining an increasing share of the global audiovisual market. Their huge catalogs feature productions from every region of the globe, allowing viewers to experience different cultures more affordably than cinema, DVDs, or cable television. Translation, and thus subtitling, allows access to this catalogue and makes it possible for distributors to "overcome language barriers around the world" (Díaz Cintas 1). However, the translation process seems ill-considered as whole. Little or no time for review causes inconsistencies and problems, such as those we have presented in this article, which impact viewer experience. In addition, pressing deadlines also impact the work of translators/subtitlers, who may have insufficient time to adhere to best practices. Meanwhile, the lack of planning could also be connected to outdated beliefs about translation in general, especially the return of concepts about "total translation", which envisage the transference of words from one language to another on a word-for-word basis. Such concepts ignore the constraints of subtitling and the complexity of the audiovisual field, including the literature published on the subject in recent decades. It seems to us that the streaming market bases its practices and recommendations on "common sense" beliefs and conceptions about translation, e.g. maximizing the number of characters per subtitle line, which years of research (particularly AVT studies) have already proven inadequate. One the most important aspects about audiovisual production is that the viewer must have time to process both images and sounds, regardless of whether subtitles are required to understand the source language.

We propose that streaming platforms should rethink their subtitle production process. We recognize that the deadlines are tight and 
that viewers want films and series as soon as possible. Nevertheless, considering what we have seen here, as well as further discussion in Translation Studies and AVT research, we suggest that more time be allotted for both review and translation, which would allow more time for condensation and rewriting, leading to more userfriendly subtitles. In addition, the review process should involve at least two steps: one performed by the subtitler and another by a proofreader. We also suggest fewer characters per line and lower reading speeds to facilitate accessibility.

\section{References}

Adão, Carlos Manuel Cunha de Jesus. Tecnologias de Streaming em Contextos de Aprendizagem. Portugal, 2017. 181f. Dissertação (Mestrado em Sistemas de Informação) - Escola de Engenharia, Universidade do Minho. Portugal, 2017. Disponível em: http://repositorium.sdum.uminho.pt/handle/1822/6400. Acesso em: 15 ago. 2018.

Auroux, Sylvian (a). A Revolução Tecnológica da Gramatização. Campinas: Editora da Unicamp, 1992.

Auroux, Sylvian (b). A filosofia da linguagem. Campinas: Editora da Unicamp, 1998.

Azevedo, Thaís de Assis. Legendagem para Streaming: novas práticas. Niterói, 2020 (inédita). 147f. Dissertação. (Mestrado em Estudos da Linguagem) Instituto de Letras, Universidade Federal Fluminense, Niterói, 2020.

Campos, Giovana C. "Mercado, Tradução e Rede Eletrônica: discursividades em pauta" Entremeios: Revista de Estudos do Discurso, v. 20, UNIVAS, MG, 2019. DOI: http://dx.doi.org/10.20337/ISSN2179-3514revistaENTREMEIOSvol20pag ina73a84

Cad. Trad., Florianópolis, v. 40, n⿳ 3, p. 222-243, set-dez, 2020. 
Carvalho, Carolina Alfaro de. A Tradução para Legendas: dos polissistemas à singularidade do tradutor. Rio de Janeiro, 2005. 160f. Dissertação (Mestrado em Estudos da Linguagem) - Departamento de Letras do Centro de Teologia e Ciências Humanas, Pontifícia Universidade Católica do Rio de Janeiro. Rio de Janeiro, 2005.

Delisle, Jean and Woodsworth, Judith. "Os tradutores e o desenvolvimento das línguas nacionais", Os Tradutores na História, Delisle, Jean and Woodsworth, Judith. (Orgs.) Trad. Sérgio Bath. São Paulo: Editora Ática, 1998. pp. 37-67

Díaz Cintas, Jorge. "Clearing the Smoke to See the Screen: ideological manipulation in audiovisual translation". Meta, Montreal: Université de Montréal, v. 57, n. 2, 2012. Avaible to: https://www.erudit.org/fr/revues/meta/2012-v57n2-meta0432/1013945ar/. Access: 16 out. 2018.

Ferreira, Ana Cláudia Fernandes. "O papel e o poder fundador da linguagem na reflexão sobre conhecimento e tecnologia". Entremeios: revista de estudos do discurso, v. 11, p. 75-98, 2015. Avaible to: http://www.entremeios.inf.br/ published/300.pdf. Acess: 11 fev. 2020.

Gil, José Ramon and Pym, Anthony. "Technology and Translation (a pedagogical overview)". Translation Technology and its Teaching, Pym, Anthony; Perestrenko, Alexander and Starrink, Bram (Eds.). Tarragona: Universitat Rovira i Virgili, 2006. 132 p. p. 5 - 19.

Gotlieb, Henrik. Subtitling: diagonal translation. Perspectives: Studies in Translatology, United Kingdom, Routledge v. 2, 1994.

Kosztolányi, Dezsö. O Tradutor Cleptomaníaco. Trad. Ladislao Szabo. São Paulo: Editora 34, 2016

Ladeira, João Martins. Imitação do excesso: televisão, streaming e o Brasil. Rio de Janeiro: Folio Digital - Letra e Imagem, 2016.

Mariani, Bethania; Medeiros, Vanise. "Divulgação científica em Análise do Discurso: investigação e inovação com base nas novas tecnologias", Enciclopédia Audiovisual Virtual de Termos, Conceitos e Pesquisas em Análise do Discurso e 
Áreas Afins: investigação, inovação, divulgação, Mariani, Bethania (org), Rio de Janeiro: Edições Makunaima e FAPERJ/CNPq, 2016. pp. 10-25.

Martinez, Sabrina. Tecnologia digital, acessibilidade e novos mercados para o tradutor audiovisual. Tradução em Revista, Rio de Janeiro: PUC-Rio, n. 11, 2011. Avaible to: https://www.maxwell.vrac.pucrio.br/rev_trad.php?strSecao=f asciculo\&fas $=27144 \& N r S e c a o=11$. Access: 8 jun. 2018 .

Mello, Giovana C. Campos de. "Tradução e Mercado: uma análise discursiva". Domínios da Lingu@gem, vol. 11, nº. 5, UFU, Uberlândia, 1649-1673, 2017. Doi: https://doi.org/10.14393/DL32-v11n5a2017-14.

Minucci, Michele Viana and Carnio, Maria Silvia. Habilidades de leitura de legendas de filmes em escolares do ensino fundamental. Pró-Fono Revista de Atualização Científica, Barueri: Sociedade Brasileira de Fonoaudiologia, v. 22, n. 3, set. 2010. Avaible to: http://www.scielo.br/scielo.php? script $=$ sci arttext\&pid $=$ S0104-56872010000300012\&lng $=$ en\&nrm $=$ iso. Access: 05 fev. 2020.

Netflix. Brazilian Portuguese Timed Text Style Guide. Última atualização consultada: 04 de junho de 2018. Avaible to: https://partnerhelp.netflixstudios. com/hc/en-us/articles/215600497-Brazilian-Portuguese-Timed-Text-Style-Guide . Access: 05 set. 2018.

Outlander. Temporadas 1, 2 e 3. Criado por: Ronald D. Moore. 2014. Avaible to Netflix. Access: mai. jun. jul. 2018.

Pedersen, Jan (a). The FAR model: assessing quality in interlingual subtitling. The Journal of Specialised Translation, United Kingdom: University of Roehampton, v. 28, 2017. Avaible to: https://mapaccess.uab.cat/publications/journal-article/ far-model-assessing-quality-interlingual-subtitling. Access: $26 \mathrm{dez} .2019$.

Pedersen, Jan (b). From old tricks to Netflix: How local are interlingual subtitling norms forstreamed television? Journal of Audiovisual Translation, London: ESIST, v. 1 n. 1, 2018. Avaible to: https://www.jatjournal.org/index.php/jat/ article/view/46. Access: 26 dez. 2019. 
Rocha, Marco; Iria Sponholz; Regina Márcia Gerber. “Apresentação.” Cadernos de Tradução [Online], 2.14 (2004): 9-15. Web. 20 mar. 2020

Szarkwska, Agnieszka; Gerber-Morón, Olívia. Viewers Can Keep Up with Fast Subtitles: evidence from eye movements. PLoS ONE, San Francisco: PLoS ONE, 13(6): e0199331, 2018. Avaible to: https://doi.org/10.1371/journal. pone.0199331. Access: 26 dez. 2019.

Recebido em: 22/04/2020

Aceito em: 05/07/2020

Publicado em setembro de 2020

Giovana Cordeiro Campos. E-mail: giovanacordeirocampos@gmail.com. ORCID: http://orcid.org/0000-0003-2494-6477.

Thais de Assis Azevedo. E-mail: thaisassis.a@gmail.com. ORCID: https://orcid. org/0000-0003-1747-1119. 